\title{
A NUMERICAL ANALYSIS OF THE RESISTANCE AND STIFFNESS OF THE TIMBER AND CONCRETE COMPOSITE BEAM
}

\author{
Ewa SZUMIGAŁA, Maciej SZUMIGAŁA ${ }^{1}$, Łukasz POLUS
}

Poznan University of Technology, Institute of Structural Engineering, Poland

\begin{abstract}
The article presents the results of a numerical analysis of the load capacity and stiffness of the composite timber and concrete beam. Timber and concrete structures are relatively new, they have not been thoroughly tested and they are rarely used because of technological constraints. One of the obstacles to using them is difficulty with finding a method which would allow successful cooperation between concrete and timber, which has been proposed by the authors of the present article. The modern idea of sustainable construction design requires the use of new more environmentally-friendly solutions. Wood as an ecological material is easily accessible, less energy-consuming, and under certain conditions more corrosion-resistant than steel. The analysis presented in the article showed that cooperation between a wooden beam and a concrete slab on profiled steel sheeting is possible. The analysed composite beam has a greater load capacity and stiffness than the wooden beam.
\end{abstract}

Keywords: composite timber and concrete beam, numerical analysis

\section{INTRODUCTION}

Sustainable development is one of the doctrines of the European Union, which controls social, economic, and environmental changes, and creates balance between profits and costs. One of the important areas of this policy is sustainable construction, which relies on natural materials, such as wood.

\footnotetext{
${ }^{1}$ Corresponding author: Institute of Structural Engineering, Faculty of Civil and Environmental Engineering, Poznan University of Technology, Piotrowo 5, 60-965 Poznan, Poland, e-mail: maciej.szumigala@put.poznan.pl
} 
Timber structures are less energy-consuming and more corrosion-resistant than other structures. However, they are less durable and have a lower load capacity and stiffness than e.g. steel structures. For these reasons, timber and concrete composite structures provide an alternative to traditional timber structures. The fundamental question is how to increase stiffness and load capacity in such composite structures. The joining together of a timber beam and a reinforced slab may be beneficial. The idea of timber and composite structures is not new. Professor Ganowicz from the Poznan University of Life Sciences worked on this issue in the previous century. The most important problem is how to develop a connector which would join both materials and finding an effective method for concrete placing.

Traditional timber structures are used as a construction material for rafter framing, wooden balk houses or Canadian houses. Glued laminated timber is used in halls where the risk of corrosion is high, for example: swimming pools and warehouses for storing fertilizers, salt and other chemicals. It is sometimes used to cover buildings of a wider span, like gyms or auditoriums, where the roof covering is made on profiled steel sheeting. The authors of the article suggest using profiled steel sheeting as the shuttering of a concrete slab. Thus, the weight of the structure will increase, but the concrete slab will effectively cooperate with the timber beam, increasing the load capacity and stiffness of the structure. However, a practical joining method which would allow cooperation between timber and concrete is necessary. There are no typical solutions to this problem on the Polish market. Typically used methods include screws, bolts or nails driven into the wooden beam, which makes it difficult to use profiled steel sheeting. The stiffness of such joints is low and their load capacity is questionable. The authors of the article are trying to patent a new type of steel shear connector, which may be used without welding. The steel profiled sheeting may be joined with the timber beam during assembly.

Currently, laboratory tests of the innovative shear connectors using [5] and of the load capacity of the timber and concrete composite beam are being prepared.

\section{THE PLASTIC AND ELASTIC RESISTANCE MOMENT OF THE COMPOSITE TIMBER AND CONCRETE BEAM ACCORDING TO EN 1994-1-1}

In order to determine the plastic and elastic resistance moment, an analysis of the timber and concrete composite beam was performed. The dimensions of the theoretical model were the same as of the experimental model. The analysed composite beam was 5.1 metre-long. The dimensions of the cross-section of the wooden beam were $200 \mathrm{~mm}$ x 300mm. The wooden beam was made of GL28h 
glued laminated timber. The beam cooperated with the compressed concrete slab which was $700 \mathrm{~mm}$ wide and $150 \mathrm{~mm}$ thick. The C35/45 concrete was poured onto the steel profiled sheeting. The cooperation between timber and concrete was made possible thanks to the shear connectors which were $19 \mathrm{~mm}$ in diameter and were arranged in pairs in each fold.

Table 1. Data

\begin{tabular}{|c|c|c|c|}
\hline Data & Symbol & Value & Unit \\
\hline Beam span & $\mathrm{L}$ & 5.10 & $\mathrm{~m}$ \\
\hline $\begin{array}{c}\text { Height of the concrete slab } \\
\text { sheeting }\end{array}$ & $\mathrm{h}$ & 150.0 & $\mathrm{~mm}$ \\
\hline $\begin{array}{c}\text { Thickness of the concrete above the steel } \\
\text { Width of the concrete slab }\end{array}$ & $\mathrm{h}_{\mathrm{c}}$ & 95 & $\mathrm{~mm}$ \\
\hline Glued laminated timber & $\mathrm{b}$ & 700 & $\mathrm{~mm}$ \\
\hline Bending strength of structural timber & $\mathrm{f}_{\mathrm{m}, \mathrm{k}}$ & 28 & $\mathrm{MPa}$ \\
\hline $\begin{array}{c}\text { Tensile/Compression strength of structural } \\
\text { timber }\end{array}$ & $\mathrm{f}_{\mathrm{t}, 0, \mathrm{k}} / \mathrm{f}_{\mathrm{c}, 0, \mathrm{k}}$ & $16.5 / 24$ & $\mathrm{MPa}$ \\
\hline $\begin{array}{c}\text { Height of the timber section } \\
\text { Width of the timber section }\end{array}$ & $\mathrm{h}_{\mathrm{w}}$ & 300 & \\
\hline Concrete & $\mathrm{b}_{\mathrm{w}}$ & 200 & $\mathrm{~mm}$ \\
\hline Mean strength of concrete & $\mathrm{f}_{\mathrm{cm}}$ & $\mathrm{C} 35 / 45$ & $\mathrm{MPa}$ \\
\hline Diameter of the shear connector & $\mathrm{d}$ & 19 & \\
\hline Steel sheeting & $\mathrm{g}$ & 1,0 & $\mathrm{~mm}$ \\
\hline Thickness of the steel sheeting & $\mathrm{f}_{\mathrm{y}}$ & 235 & $\mathrm{MPa}$ \\
\hline Steel
\end{tabular}

The width of the concrete slab was smaller than the effective width which was obtained using [5]. The elastic resistance moment was $268.6 \mathrm{kNm}$, while the plastic resistance moment was $277.7 \mathrm{kNm}$. For the thinner concrete slab $(100 \mathrm{~mm})$ the plastic resistance moment was $228.2 \mathrm{kNm}$. The elastic resistance of the timber beam was $84.0 \mathrm{kNm}$. The load capacity of the composite beam was 3.2 times higher in the elastic model and 3.3 times higher in the plastic model than the load capacity of the timber beam. However, these results are very optimistic, because timber is not a plastic material and is non-linear before the rupture (Fig. 5.). The load capacity of the shear connectors is also important.

\section{A NUMERICAL ANALYSIS OF THE COMPOSITE TIMBER AND CONCRETE BEAM}

In order to accurately determine the load capacity of the composite beam, a 3D numerical model was prepared. The model consisted of a timber beam and a concrete slab on steel sheeting. It is presented in Fig. 1. The slab and the 
beam were joined using the shear connectors embedded in the concrete slab. The shear connectors are presented in Fig. 3.

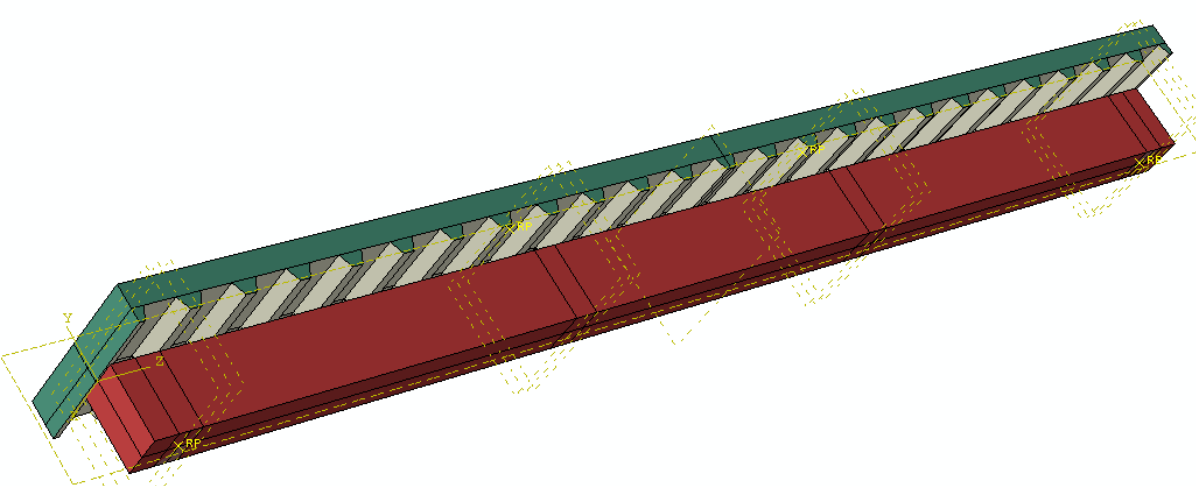

Fig. 1. A 3D model of the composite timber and concrete beam

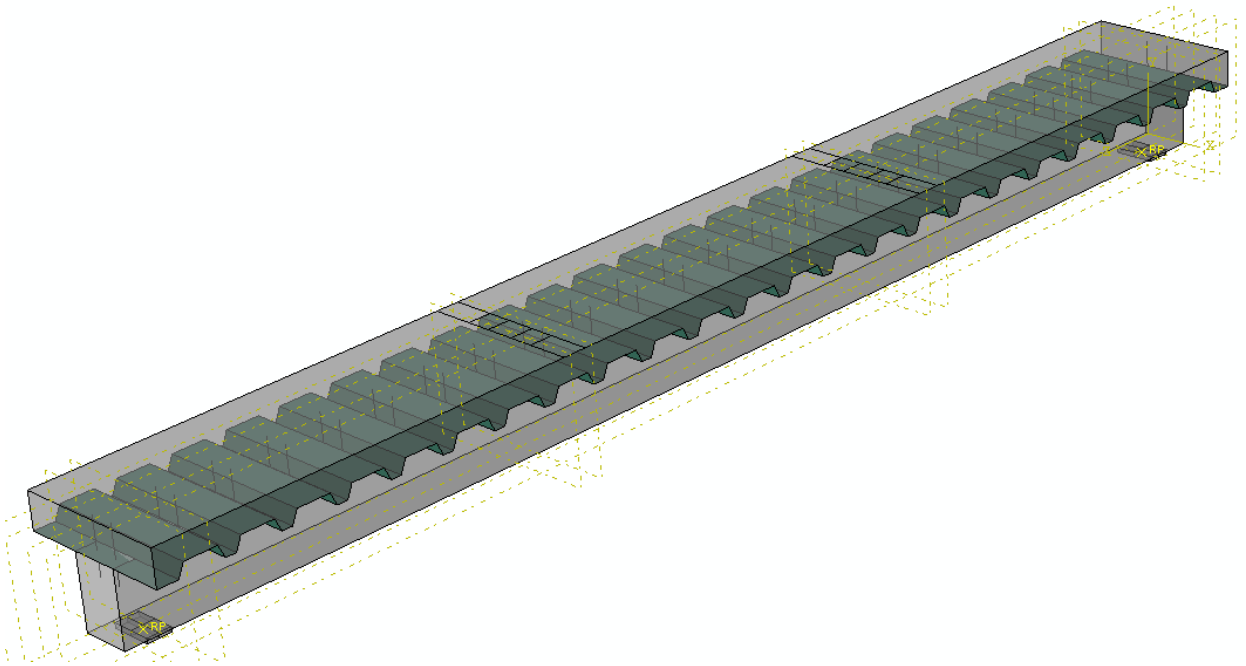

Fig. 2. Steel sheeting as the skin of the concrete slab

The geometry of the model was replaced by finite elements. The model of the concrete slab and the model of the timber beam were created using C3D8 eightnode solid elements (Fig. 4). The model of the shear connectors was created using B31 beam elements. The steel sheeting was created as the skin of the concrete slab (Fig. 2) and the S4R four-node shell elements were used. 


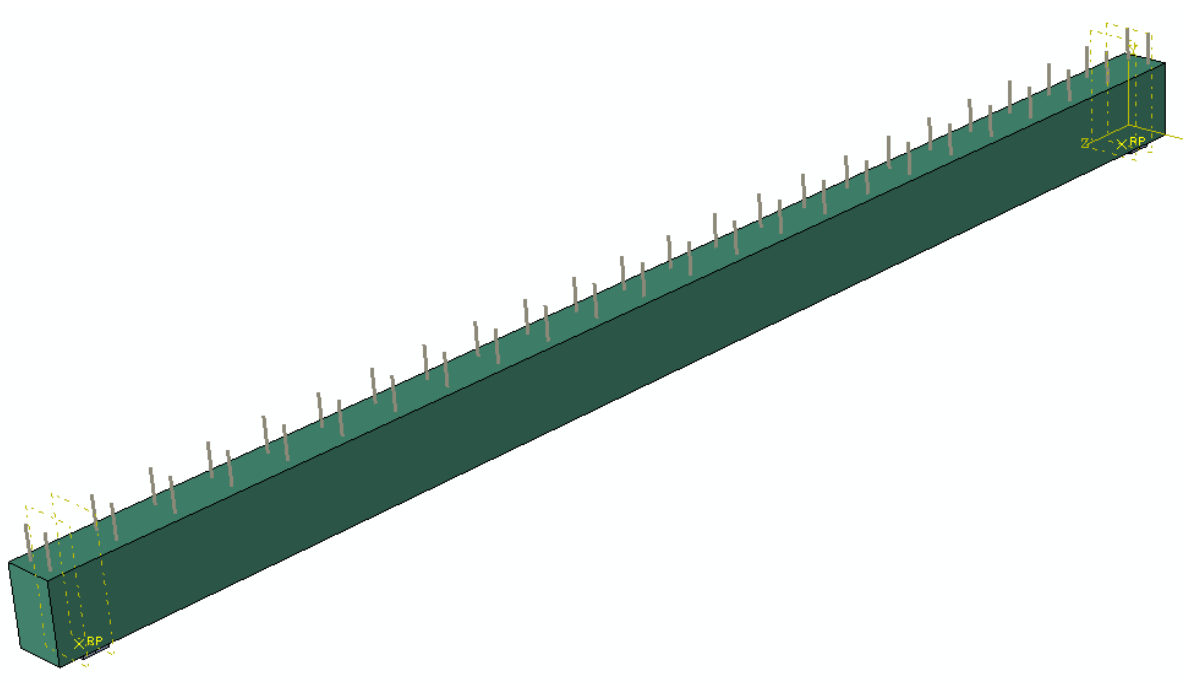

Fig. 3. Shear connectors

The model was meshed and consisted of 32626 nodes and 29962 elements (Fig. 4). Taking into account the longitudinal symmetry and the transverse symmetry of the element, only one fourth of the composite beam was analysed.

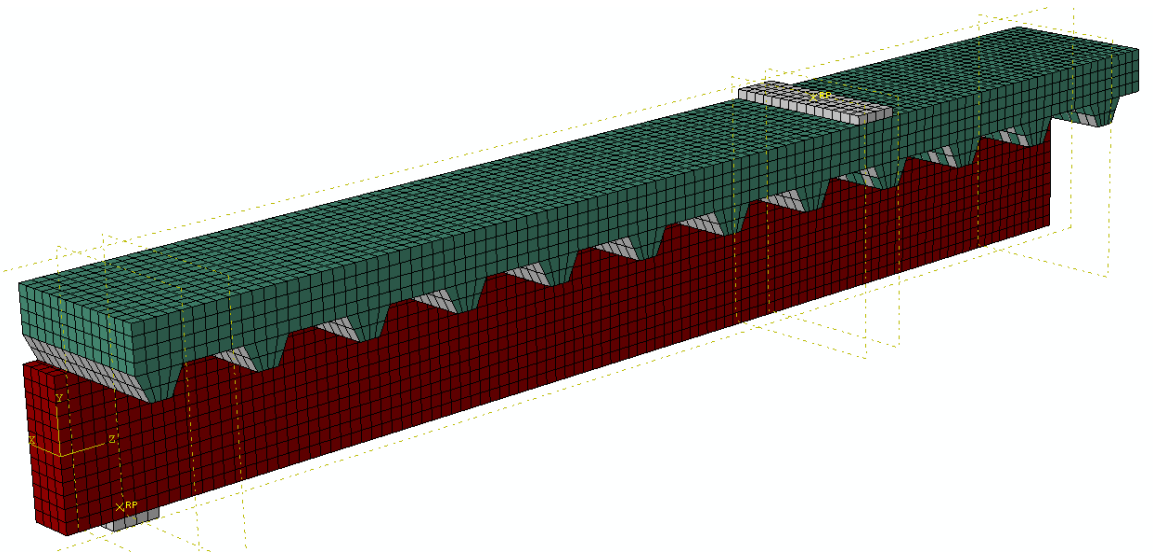

Fig. 4. Mesh

In the numerical calculations the individual and non-linear laws of physics of particular materials were used (see Fig.5). The plasticity of structural steel and the non-linear behavior of concrete in a 3D space were taken into account. 

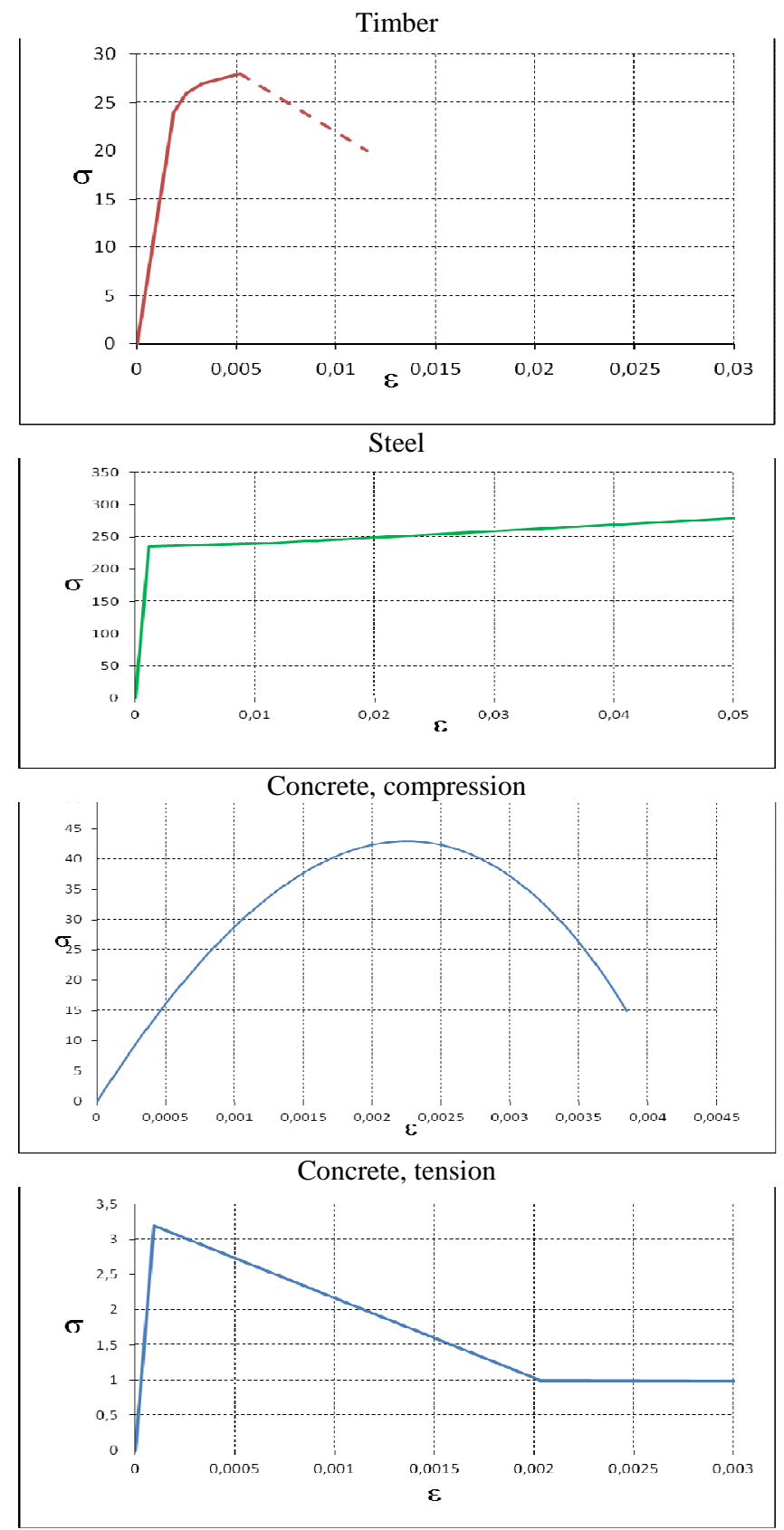

Fig. 5. The laws of physics for each material 
Steel was modelled as an elastic-plastic material with reinforcement, whereas concrete was modelled as an elastic-plastic material with isotropic damage (Concrete Damage Plasticity). For wood, a non-linear elastic model was used. Thanks to the laws of physics, the time step in which the model reached the load capacity was easy to determine. The laws of physics were derived from the Eurocodes. The calculations were performed using the Abaqus-Standard procedure and the Newton-Raphson method. The load was applied in the form of kinematic displacement, as in a four-point bending beam schema. It was assumed that the resistance of the beam was reached when there was a local extreme on the static equilibrium path.

\section{RESULTS OF THE NUMERICAL ANALYSIS}

As a result of the calculation, a static equilibrium path was obtained (Fig. 6.). The maximum reaction was $90.97 \mathrm{kN}$ and was obtained in the $29^{\text {th }}$ step of the calculation, where the maximum deflection of the beam was $62.84 \mathrm{~mm}$. The deflection under the force was $56.41 \mathrm{~mm}$. Taking into account the fact that the symmetry was applied, the maximum reaction for the entire element was 181.94 $\mathrm{kN}$ and the bending resistance was $309.3 \mathrm{kNm}$. This value was higher than the previously calculated elastic and plastic resistance.

$$
268.6 \mathrm{kNm}<309.3 \mathrm{kNm} \text { and } 277.7 \mathrm{kNm}<309.3 \mathrm{kNm}
$$

Resistance is not only important factor in the design practice, the serviceability limit state is equally important. For the composite beam the limit deflection was $20.4 \mathrm{~mm}$. In the $11^{\text {th }}$ step the deflection was $19.28 \mathrm{~mm}$ and the bending resistance was $192.2 \mathrm{kNm}$. For the timber beam, the bending resistance was 41.8 $\mathrm{kNm}$ when the serviceability limit state was taken into account. The gain amounted to $192.2 / 41.8=4.6$.

The resistance of the composite beam may be lower because of the load capacity of the shear connectors. The stresses of the shear connectors are presented in Fig. 7. Some of the shear connectors plasticized.

The displacement of the concrete slab relative to the timber beam amounted to $5.6 \mathrm{~mm}$. The tests of flexibility of the shear connectors may help improve the model. Taking into account the incomplete utilization of the load capacity of the concrete slab (Fig. 8), the thickness of the concrete slab may be lower. The thickness was reduced to $11 \mathrm{~cm}$. As a result of the calculation, the static equilibrium path was obtained (Fig. 9.). It is worth noting that the strain energy curve had a local extreme (Fig. 10) and may also be used to determine the local capacity of the beam [4]. 


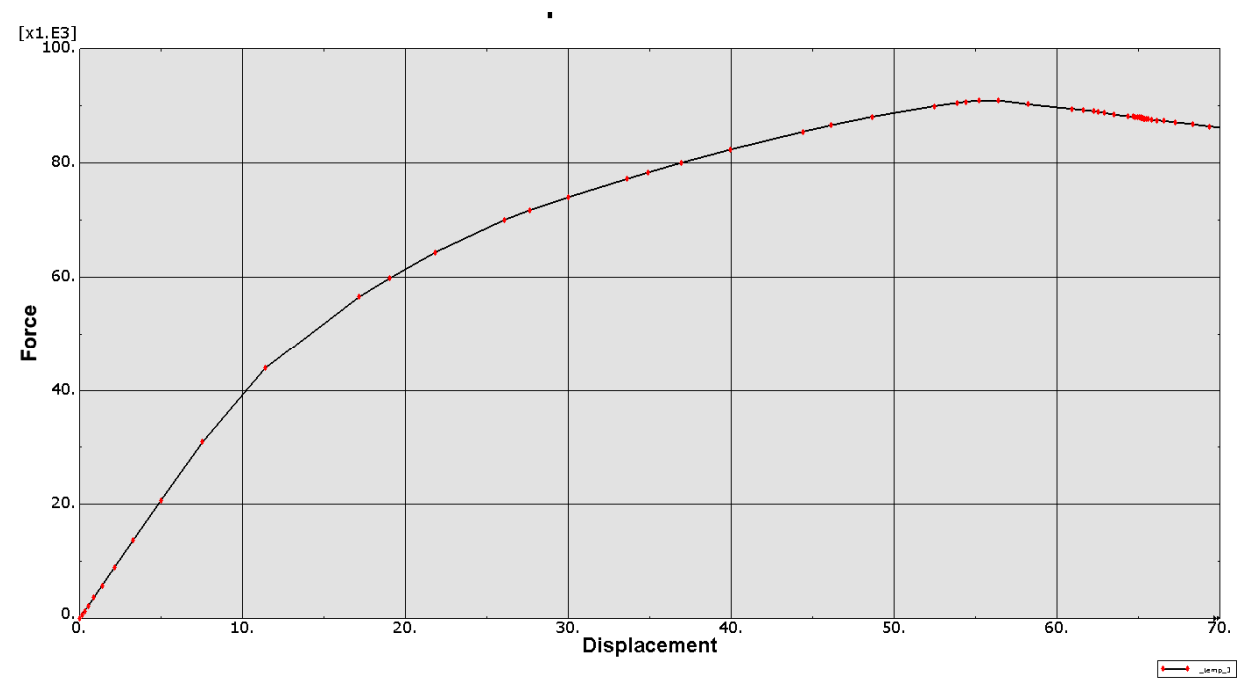

Fig. 6. The static equilibrium path force - displacement

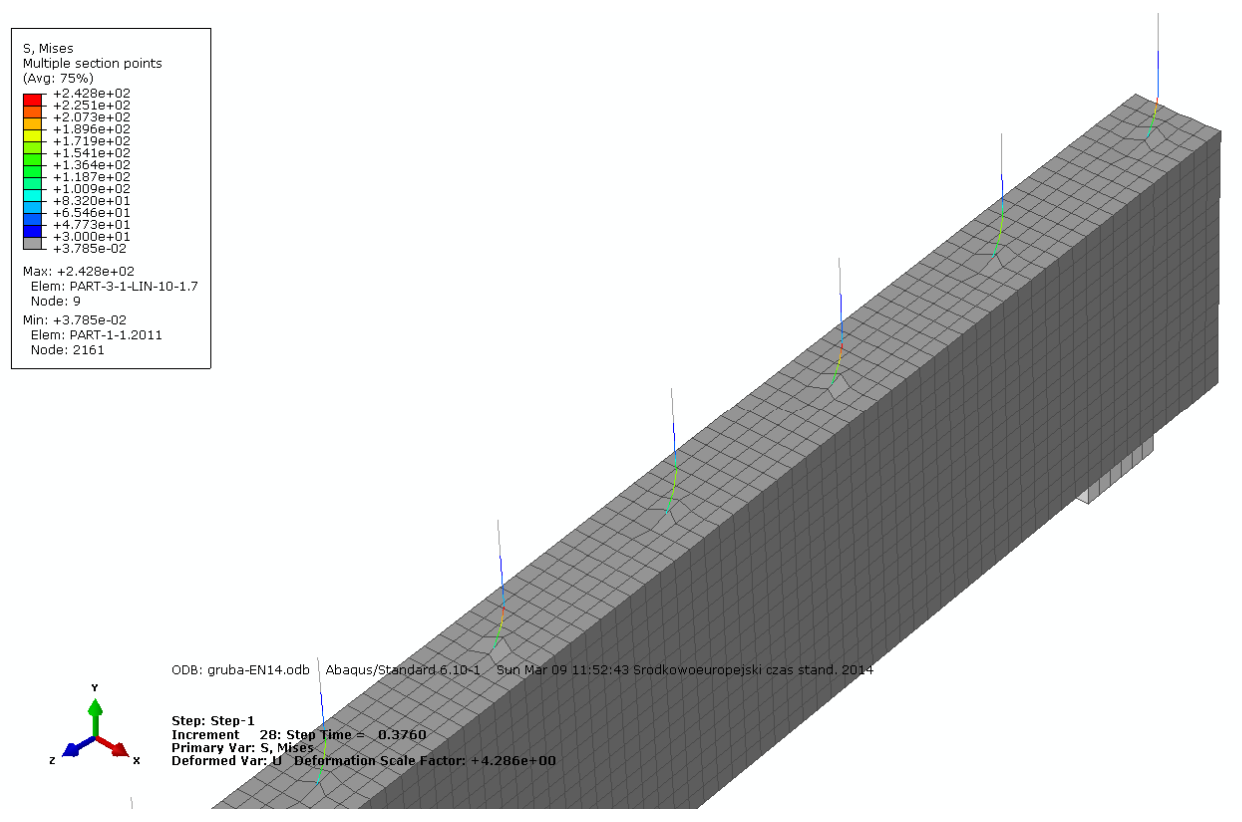

Fig. 7. The stresses of the shear connectors 


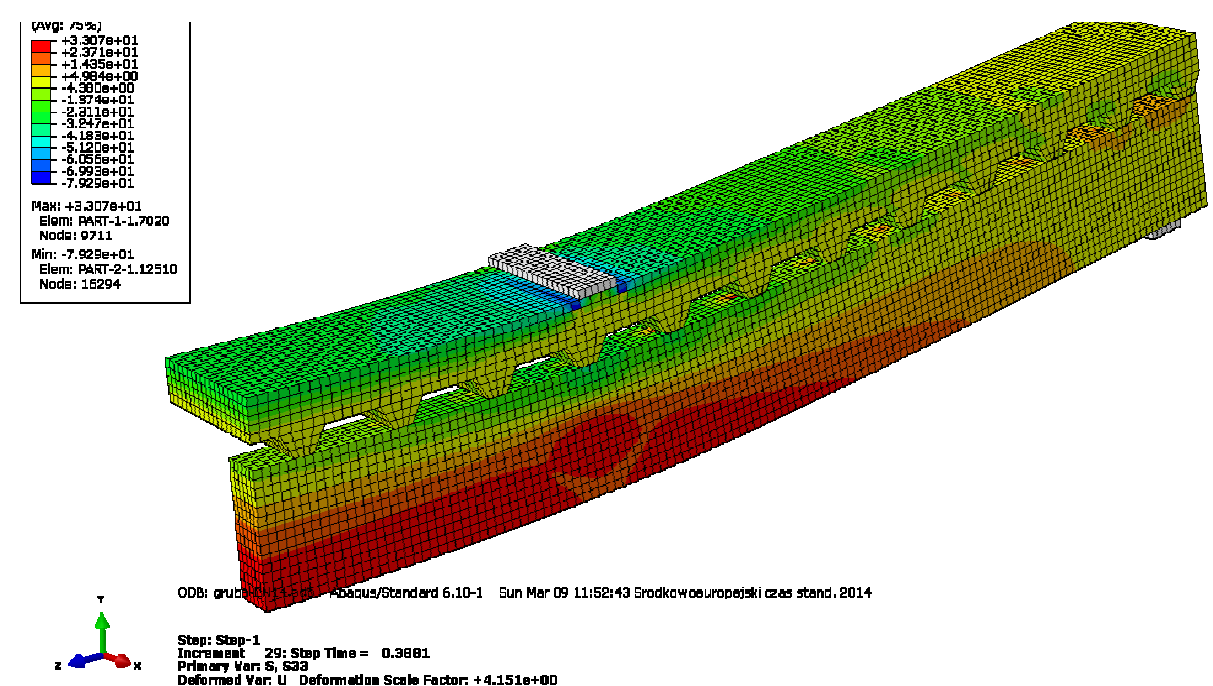

Fig. 8. The stresses in ultimate limit state

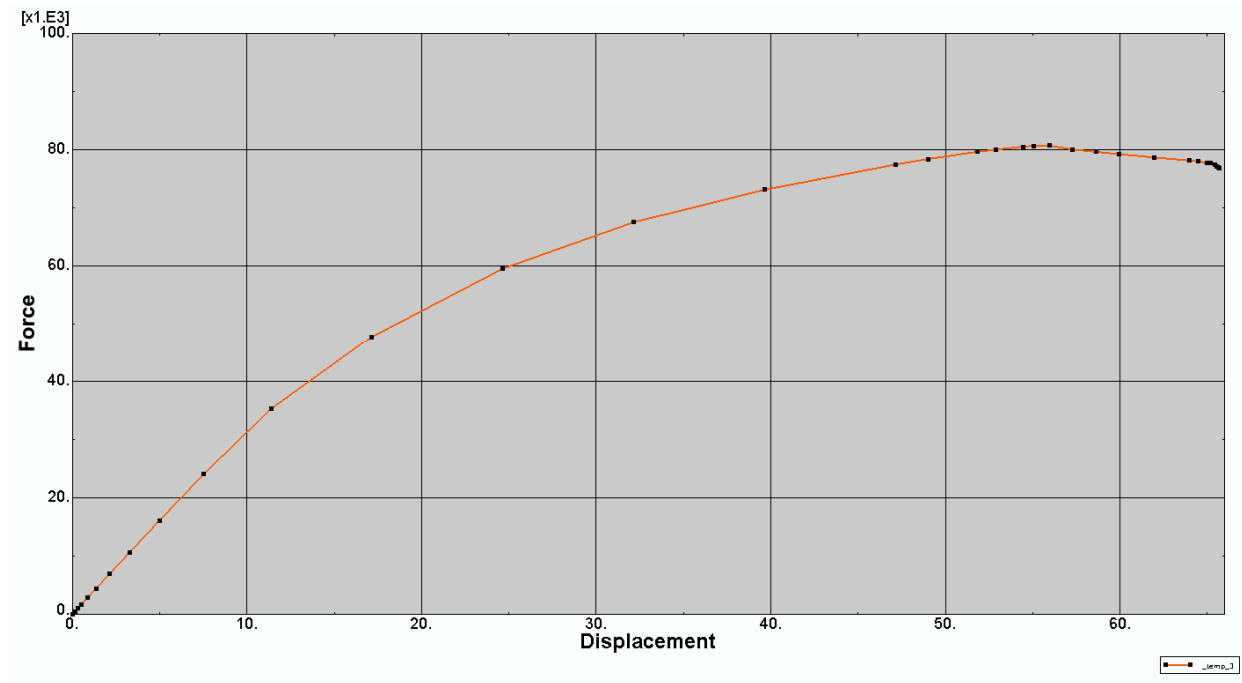

Fig. 9. The static equilibrium path force - displacement for the thinner slab 


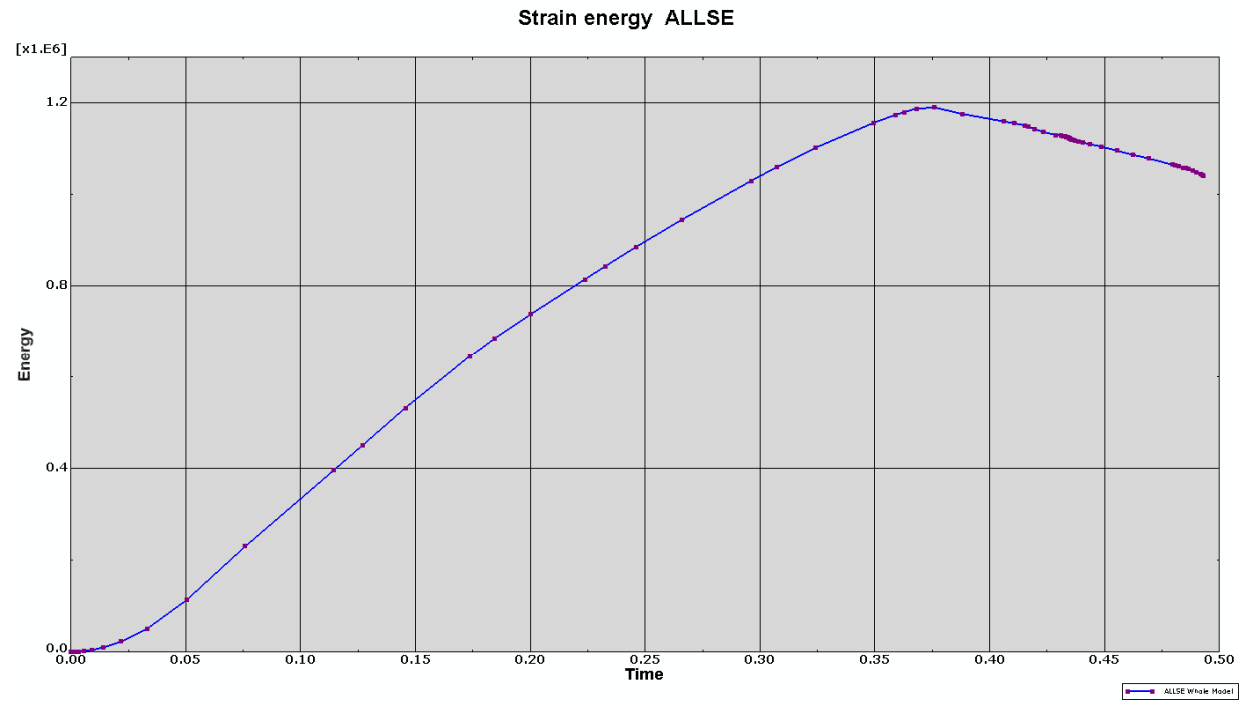

Fig. 10. The strain energy curve

The results obtained in the analyses are presented in Table 2.

Table 2. Results of the numerical calculation

\begin{tabular}{|c|c|c|c|c|}
\hline \multirow{2}{*}{\multicolumn{2}{|c|}{$\begin{array}{l}\text { Timber beam (elastic model) } \\
\text { Tistic model }\end{array}$}} & \multirow{2}{*}{$\begin{array}{c}\begin{array}{c}\text { Moment } \\
{[\mathrm{kNm}]}\end{array} \\
84.0 \\
\end{array}$} & \multirow{2}{*}{$\begin{array}{c}\begin{array}{c}\text { Deflection } \\
\text { [mm] }\end{array} \\
41.0 \\
\end{array}$} & \multirow{2}{*}{ 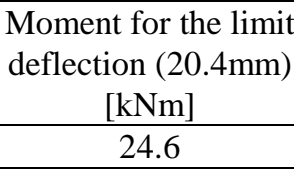 } \\
\hline & & & & \\
\hline \multirow{4}{*}{ 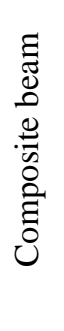 } & $\begin{array}{l}\text { Elastic model } \\
\text { PN-EN } 1994\end{array}$ & 268.6 & 17.1 & ------ \\
\hline & $\begin{array}{c}\text { Plastic model } \\
\text { using PN-EN } 1994\end{array}$ & 277.7 & ------ & ------ \\
\hline & $\begin{array}{l}\text { Numerical analysis } \\
\text { Thick slab }\end{array}$ & 309.3 & 62.8 & 192.2 \\
\hline & $\begin{array}{l}\text { Numerical analysis } \\
\text { Thin slab }\end{array}$ & 274.6 & 62.5 & 162.5 \\
\hline
\end{tabular}

\section{CONCLUSIONS}

The analyses conducted revealed that the proposed design solution, the timber and concrete composite beam may be very advantageous:

- the load capacity increases at least 3 times

- the stiffness increases at least 7 times 
- the new type of steel shear connectors may allow cooperation between concrete and timber and may be used in new solutions

- the numerical model is an efficient analytical tool, but it needs improvements

- the laboratory tests of the innovative shear connectors and the composite timber and concrete beam make it possible to create a more accurate model in the Abaqus program

- there is lack of references of experimental results to compare them with numerical results presented in this article, the laboratory tests of the composite timber and concrete beam are needed

- on the basic of results given in the paper, connection stiffness function $\mathrm{k}(\mathrm{x})$ can be determined, the variability of this function may show how flexible the connection is.

\section{ADDITIONAL INFORMATION}

Financial support by the 01/11/DSPB/0305 is kindly acknowledged. The authors of the article wish to thank RYWAL-RHC for the shear connectors used for the tests.

\section{REFERENCES}

1. Giżejowski M.: Budownictwo ogólne, Tom 5, Stalowe konstrukcje budynków, projektowanie wedtug eurokodów z przyktadami obliczeń, Arkady, 2010.

2. Kmiecik P., Kamiński M.: Modelling of reinforced concrete structures and composite structures with concrete strength degradation taken into cosidera-tion, Archives of Civil and Mechanical Engineering, Vol. XI, No. 3, 2011.

3. Kucharczuk W., Labocha S.: Konstrukcje zespolone stalowo-betonowe budynków, Arkady, Warszawa 2007.

4. Szumigała M.: The numerical analysis of a critical surface $M-N$ for steelconcrete composite section, CMM-2005 - Computer Methods in Mechanics, June 21-24, 2005, Częstochowa, Poland.

5. PN-EN 1994-1-1, Eurokod 4, Projektowanie zespolonych konstrukcji stalowo-betonowych Część 1-1: Reguty ogólne i reguty dla budynków, Polski Komitet Normalizacyjny 2008.

6. PN-EN 1995-1-1, Eurokod 5, Projektowanie konstrukcji drewnianych, Czesść 1-1: Reguty ogólne, Polski Komitet Normalizacyjny 2011. 
7. PN-EN 1992-1-1, Eurokod 2, Projektowanie konstrukcji z betonu, Część 11: Reguły ogólne i reguty dla budynków, Polski Komitet Normalizacyjny 2008.

\section{ANALIZA NUMERYCZNA NOŚNOŚCI I SZTYWNOŚCI BELKI ZESPOLONEJ DREWNIANO - BETONOWEJ}

\section{Streszczenie}

W artykule przedstawiono wyniki analizy numerycznej nośności i sztywności belki zespolonej drewniano-betonowej. Konstrukcje drewniano-betonowe nie są zupełną nowością, lecz nie są jeszcze dostatecznie przebadane, a brak powszechniejszego ich stosowania wynika $\mathrm{z}$ ograniczeń technologicznych. Jedną z przeszkód jest sposób zapewnienia współpracy drewna $\mathrm{z}$ betonem, co zostało przez autorów zaproponowane. Współczesna idea budownictwa zrównoważonego wymaga od projektantów stosowania nowych rozwiązań, które będą bardziej przyjazne środowisku. Drewno jako materiał ekologiczny jest łatwo dostępne, mniej energochłonne i w pewnych warunkach ma większą odporność na korozję niż stal. Analiza przedstawiona w artykule wykazała, że możliwa jest współpraca belki drewnianej i betonowej płyty wykonanej na blasze fałdowej. Analizowana belka drewniano-betonowa wykazała wielokrotnie większą nośność i sztywność w stosunku do belki drewnianej.

Słowa kluczowe: belka zespolona drewno-beton, analiza numeryczna

Editor received the manuscript: 25.07.2014 